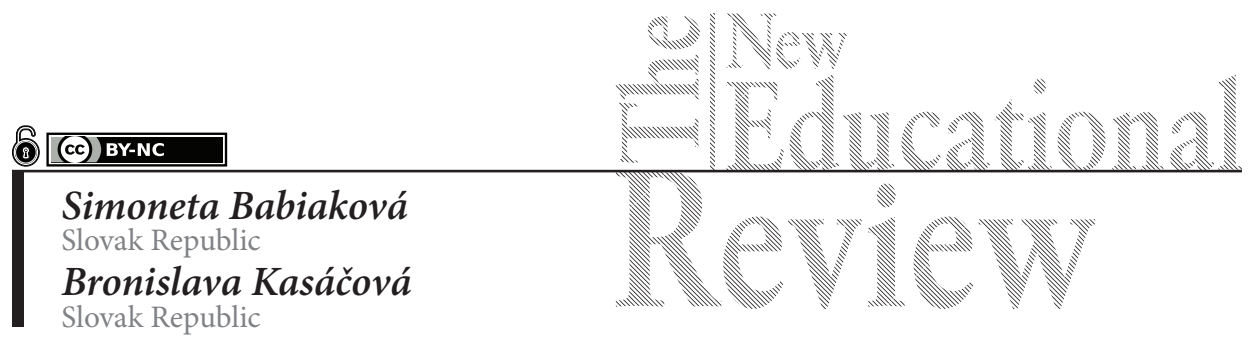

\title{
International Comparison of the Social Context of Younger Pupils' Reading
}

DOI: $10.15804 /$ tner.2021.63.1.08

\begin{abstract}
The study builds on the article published by the authors in No. 3/2020 ${ }^{1}$.Its aim is to present further results of the international comparative analysis. The study deals with the revealed social context influencing younger pupils' reading. Respondents' statements were obtained through a questionnaire of own design. Items related to the social context arose from a qualitative analysis of focus interviews in the previous research phase. The research sample consisted of 693 Slovak, 254 Czech and 248 Polish pupils 9-10 years old. Findings showed differences between national groups. Pupils prefer reading with someone; mothers are the most important partners for sharing, fathers read slightly more often only to Polish pupils. Polish pupils prefer reading aloud in front of an audience the most. Teachers as partners for reading interests are the most prominent in the Polish group. The study presents findings and differences in international comparisons of the social context of younger pupils' reading.
\end{abstract}

Key words: younger pupils, social context of reading, international comparison, research on Slovak, Czech and Polish pupils' reading

1 Babiaková, s. \& Kasáčová, B. (2020): Reading Preferences of Younger Learners in Slovak-Czech-Polish Comparison. The New Educational Review 61, No. 3, 38 - 50. DOI: 10, 15804/ tner.2020.61.3.03 


\section{Introduction}

In recent decades, the social context and the life style of families with children have changed. Many researches point out to the association between social isolation and some warning signs showing decline in reading among children in their free time. Their declining reading skills, necessary for learning and working with text, are also warning. This is reflected also at higher levels of education and in the self-learning ability. The study by Renuga \& Kanchana (2015) points out to the fact that the teacher should understand students' conceptions of reading for promoting their interest in reading and enhancing their reading skills. In her publication, R. Levy (2011) presents scientific evidence showing that some of tried and tested approaches to teaching reading may be counter-productive and causing younger pupils to lose confidence in their abilities as readers. It is necessary to reflect on the current reading curriculum and ways in which the reading and pupils' reading can be developed to match the changing literacy.

Reading as a highly developed skill and socially accepted activity is the basic precondition for education at higher levels of education. The foundations of reading are laid down in primary education, and they are not only about mastering the technique and skill, but also about forming a habit and need. Reading preferences in international comparison were the subject of our previous study (Babiaková, Kasáčová, 2020, 38 -50). This text focuses on findings about the social context of younger pupils' reading.

Reading is influenced also by personal perception of its value, with the value hierarchy arising in close connection with the society the person is a member of. Perception of the value of reading at a younger age is a predictor of leisure-time reading at an older age. Durik, Vida, Eccles (2006) as well as voices of experienced professionals from schools and libraries point to a significant decline in reading with children's increasing age. There are also sceptical views that the reading is disappearing (Rideout, 2014; Chaves, 2017; Ducharme, 2018). The social context of reading and reading preferences in children and adolescents are also changing (Australian Kids and Family Reading Report. 2016; Loh, \& Baoqi, 2018). It is a wellknown fact that the culture and social-economic status of family influences not only pupil performance in learning and reading literacy, but also pupil reading, thus the relationship to reading and reading enthusiasm. For the interest in reading emergence and development, the reading environment, material and literary stimulation as well as social support and response are important.

Our contribution is focused on comparison of the social context and social sharing of reading among Slovak, Czech and Polish readers aged 9 - 10 years. 
The social context of reading, as studied here, arose based on the initial phase of our three-year research project ${ }^{2}$. Focus interviews were used to find out how younger and older pupils reflected their emotions and needs for social sharing, receiving and passing on the reading experience. The following social ties were found: parents, grand parents, teachers, friends (real and virtual), siblings, and the types of social situations: listening to reading, reading aloud, reading in front of an audience, conversations about the read text, interest of parents and those around in children's reading, school reading support.

The countries Slovakia, Poland and Czech Republic have similar socio-political starting points and traditions, thus pupil research samples are suitable for comparison. However, the development in recent years shows emergence of significant differences due to different cultures, educational policies, educational preferences and educational reforms. This appears also in the differences in international measurements of reading literacy. PIRLS measurements and comparisons of pupils' reading literacy in the countries studied show an apparent rise of Polish pupils from the $29^{\text {th }}$ to the $6^{\text {th }}$ place over 10 years (PIRLS, 2016). Poland embarked on the concept of integrated curriculum for primary education, which could reflect also in the results of the reading literacy measurements. In Poland, reading is not the goal and means only of literature classes, but it is incorporated in all subjects.

Our formulation of the research problem is thus: in terms of the social context of reading, there are fundamental differences between Slovak, Czech and Polish pupils; we are interested in the extent to which these differences are significant. Pupils' statements showing the need for social and emotional sharing of read texts and reading experiences inspire the rationale of this research problem. Focus interviews reveal that children want to discuss their "experiences with literature" with their school mates, present at school what they have read about, they have a peer group where they share "good books", enjoy occasions to talk about them at school. We describe this phenomenon, which we call the social context of reading, in detail in our study (Babiaková \& Kasáčová, 2020, pp. 6341 - 6351). It compares 10 -year old and 13-year old Slovak pupils from the ontogenetic aspect. The major research findings are summarized as follows (ibid. pp. $6341-6351$ ):

- The proportion of avid readers declines rapidly with age;

- Younger pupils read with enthusiasm when there is a response from people around. Older pupils' reading evokes little interest of people around;

2 This text was created under the project VEGA No. 1/0455/18 titled "Research and Development of Reading Enthusiasm with Younger School-Age Learners", principal investigator doc. PaedDr. Simoneta Babiaková, PhD. 
- Although older pupils read better, they do not like reading in public;

- The difference between avid readers and groups of other reading levels is increasing;

- Interest of people around in pupils' reading declines with pupils' age; fathers' interest is extremely low;

- With pupils' age, the proportion of friends in the role of advisers and discussion partners increases;

- Teachers talk very little about and are very little interested in pupils' leisure reading in both groups. At a younger age, reading is encouraged in school environment; at the secondary level, it is a matter only of teachers of language and literature;

- Older pupils' reading is significantly reduced to obligatory reading, leisure reading wanes, and reading looses its value as a social currency.

\section{Methodology and research sample}

Research data were obtained through a questionnaire of own design in three language versions. It consisted of 46 items (Babiaková \& Kasáčová, 2020, pp. 6341 - 6351). The items were formulated as statements based on focus interviews with pupils. The first group of items gathered data about the respondent and school, the second the reader's characteristics. This included items based on which respondents were distributed to four reading levels (A - Avid reader, I - Interested reader, $\mathrm{G}$ - Literate non-reader, $\mathrm{N}$ - Illiterate non-reader). We examined phenomena characterizing the social context of younger pupils' reading.

The research sample for the purpose of the study consisted of 1195 pupils in total, aged 9 - 10 years, from Slovak, Czech and Polish schools. The research sample was obtained by convenience sampling (Tab. 1).

Table 1. Characteristics of the Slovak, Czech and Polish sample

\begin{tabular}{lcccccccccc}
\hline & $\begin{array}{c}\text { A - Avid reader } \\
\mathrm{N} \%\end{array}$ & \multicolumn{2}{c}{$\begin{array}{c}\text { I - Interested } \\
\text { reader } \\
\mathrm{N} \%\end{array}$} & \multicolumn{2}{c}{$\begin{array}{c}\text { G - Literate } \\
\text { non-reader } \\
\mathbf{N} \%\end{array}$} & $\begin{array}{c}\text { N - Illiterate } \\
\text { non-reader } \\
\mathbf{N} \%\end{array}$ & \multicolumn{2}{c}{$\begin{array}{c}\text { Total } \\
\text { N \% }\end{array}$} \\
\hline SK & 309 & 44.59 & 268 & 38.67 & 110 & 15.87 & 6 & 0.87 & 693 & 100 \\
\hline CZ & 76 & 29.97 & 120 & 47.24 & 54 & 21.26 & 4 & 1.58 & 254 & 100 \\
\hline PL & 46 & 18.55 & 114 & 45.97 & 82 & 33.06 & 6 & 2.42 & 248 & 100 \\
\hline
\end{tabular}


After the experience of ontogenetic comparison, we were interested in international comparison. The goal was to find out differences and analogical tendencies in younger pupils in these three countries because Poland and the Czech Republic began to support reading not only as an important precondition for literacy, but also as a significant way of spending free time and support for social sharing. Research questions focused on the popularity of reading and sharing of the read text in a social group, identification of specific persons playing a role in the social context of reading among pupils of the $4^{\text {th }}$ class, and on the social context of reading related to school.

The primary analysis of research findings of the descriptive nature about the social context of reading identified remarkable phenomena. They were tested statistically subsequently. Since the variables were nominal, chi-square was used. Pairs were compared, and statistical findings are presented only where statistical significances were determined. Partial comparisons used only extreme values strong agreement, and, for reverse items, disagreement.

\section{Results}

At a younger school age, it is quite natural part of children's lives that their parents, grand parents or older siblings read to them. At this period at school, good readers from among pupils replace the teacher's reading. The descriptive analysis of data identified an obvious difference in the item I enjoy listening to others' reading in the Polish sample. There is a statistically significant difference at the significance level $\mathrm{p}<0.001$ between Polish and Czech pupils, at the significance level of $\mathrm{p}<0.01$ between Polish and Slovak pupils. Polish pupils' agreement with this statement is the most prominent. It is evident in the group of Polish avid readers (A). The sum of both agreements is $85 \%$ in Poland, $67 \%$ in the Czech Republic and $71 \%$ in Slovakia (Tab. 2). The reading culture is associated with the willingness and liking for listening to text read.

Table 2.

\begin{tabular}{|c|c|c|c|c|c|c|c|c|c|c|c|c|}
\hline \multicolumn{13}{|c|}{ I enjoy listening to others' reading } \\
\hline \multirow{2}{*}{ 莺 } & \multicolumn{3}{|c|}{$\begin{array}{c}\text { I agree very much } \\
\%\end{array}$} & \multicolumn{3}{|c|}{$\begin{array}{c}\text { I agree } \\
\%\end{array}$} & \multicolumn{3}{|c|}{$\begin{array}{c}\text { I do not agree } \\
\%\end{array}$} & \multicolumn{3}{|c|}{$\begin{array}{c}\text { I cannot answer } \\
\%\end{array}$} \\
\hline & SK & $\mathrm{CZ}$ & PL & SK & $\mathrm{CZ}$ & PL & SK & $\mathrm{CZ}$ & PL & SK & $\mathrm{CZ}$ & PL \\
\hline A & 33.7 & 30.3 & 54.4 & 43.0 & 36.8 & 30.4 & 14.6 & 25.0 & 8.70 & 8.74 & 7.89 & 6.52 \\
\hline I & 29.48 & 23.33 & 44.74 & 40.30 & 48.33 & 34.21 & 11.57 & 20.00 & 13.16 & 18.66 & 8.33 & 7.89 \\
\hline $\mathrm{G}$ & 31.82 & 24.07 & 32.93 & 30.91 & 31.48 & 31.71 & 15.45 & 18.52 & 23.17 & 21.82 & 25.93 & 12.20 \\
\hline
\end{tabular}


Simoneta Babiaková, Bronislava Kasáčová

\begin{tabular}{|c|c|c|c|c|c|c|c|c|c|c|c|c|}
\hline \multicolumn{13}{|c|}{ I enjoy listening to others' reading } \\
\hline \multirow{2}{*}{ 常 } & \multicolumn{3}{|c|}{$\begin{array}{c}\text { I agree very much } \\
\%\end{array}$} & \multicolumn{3}{|c|}{$\begin{array}{c}\text { I agree } \\
\%\end{array}$} & \multicolumn{3}{|c|}{$\begin{array}{c}\text { I do not agree } \\
\%\end{array}$} & \multicolumn{3}{|c|}{$\begin{array}{c}\text { I cannot answer } \\
\%\end{array}$} \\
\hline & SK & $\mathrm{CZ}$ & PL & SK & $\mathrm{CZ}$ & PL & SK & $\mathrm{CZ}$ & PL & SK & $\mathrm{CZ}$ & PL \\
\hline $\mathrm{N}$ & 50.00 & 25.00 & 16.67 & 33.33 & 50.00 & 16.67 & 0.00 & 0.00 & 0.00 & 16.67 & 25.00 & 66.67 \\
\hline $\begin{array}{l}\text { To- } \\
\text { tal }\end{array}$ & 31.89 & 25.59 & 41.94 & 39.97 & 41.34 & 32.26 & 13.42 & 20.87 & 15.32 & 14.72 & 12.20 & 10.48 \\
\hline
\end{tabular}

The item I enjoy reading to somebody monitors "passive" reading and the item I enjoy reading aloud in front of the entire class addresses pupils' reading activity in the social context. There is an obvious difference in the Slovak sample.

The difference between Slovak and Czech pupils is statistically significant at the level of $\mathrm{p}<0.01$ in favour of Slovak pupils. The difference between Slovak and Polish pupils is not significant. Czech pupils like reading aloud to someone else the least, Slovak the most. Czech respondents (38\%) in comparison with Slovak (21\%) and Polish (25\%) dislike this activity. A detailed view of the reading levels shows that mainly avid readers (Tab. 3) enjoy reading to someone else.

Table 3.

\begin{tabular}{|c|c|c|c|c|c|c|c|c|c|c|c|c|}
\hline \multicolumn{13}{|c|}{ I enjoy reading to somebody } \\
\hline \multirow{2}{*}{$\stackrel{\infty}{\stackrel{d}{d ~}}$} & \multicolumn{3}{|c|}{$\begin{array}{c}\text { I agree very much } \\
\%\end{array}$} & \multicolumn{3}{|c|}{$\begin{array}{l}\text { I agree } \\
\%\end{array}$} & \multicolumn{3}{|c|}{$\begin{array}{c}\text { I do not agree } \\
\%\end{array}$} & \multicolumn{3}{|c|}{$\begin{array}{c}\text { I cannot answer } \\
\%\end{array}$} \\
\hline & SK & $\mathrm{CZ}$ & PL & SK & $\mathrm{CZ}$ & PL & SK & $\mathrm{CZ}$ & PL & SK & $\mathrm{CZ}$ & PL \\
\hline $\mathrm{A}$ & 37.86 & 34.21 & 34.78 & 42.72 & 32.89 & 47.83 & 12.94 & 23.68 & 15.22 & 6.470 & 9.210 & 2.170 \\
\hline $\mathrm{I}$ & 15.30 & 12.50 & 16.67 & 44.03 & 33.33 & 35.96 & 23.13 & 40.00 & 24.56 & 17.54 & 14.17 & 22.81 \\
\hline G & 2.730 & 0.000 & 10.98 & 21.82 & 12.96 & 35.37 & 40.00 & 55.56 & 30.49 & 35.45 & 31.48 & 23.17 \\
\hline $\mathrm{N}$ & 0.000 & 0.000 & 0.000 & 33.33 & 0.000 & 0.000 & 33.33 & 0.000 & 16.67 & 33.33 & 100.00 & 83.33 \\
\hline $\begin{array}{l}\text { To- } \\
\text { tal }\end{array}$ & 23.23 & 16.14 & 17.74 & 39.83 & 28.35 & 37.10 & 21.36 & 37.80 & 24.60 & 15.58 & 17.72 & 20.56 \\
\hline
\end{tabular}

In primary education, reading aloud in front of the whole class is system part of education. The Polish sample appears significantly different in comparison with the Czech sample in the item I enjoy reading aloud in front of the entire class.

The difference between Polish and Czech pupils is statistically significant at the level of $\mathrm{p}<0.01$ in favour of Polish pupils. The difference between Polish pupils and Slovak pupils is not significant. Overall, it can be stated that Slovak and Czech children, in difference to Polish children, do not like reading in public. All groups show that the disagreement rises with the decline of respondents' reading levels. 
Although the sum of both levels of agreement is almost comparable in the countries, it is considerably different in Polish avid readers (A) exceeding all others in their unrivalled strong agreement (Tab. 4).

Table 4.

\begin{tabular}{|c|c|c|c|c|c|c|c|c|c|c|c|c|}
\hline \multicolumn{13}{|c|}{ I enjoy reading aloud in front of the entire class } \\
\hline \multirow{2}{*}{$\frac{\infty}{d}$} & \multicolumn{3}{|c|}{$\begin{array}{c}\text { I agree very much } \\
\%\end{array}$} & \multicolumn{3}{|c|}{$\begin{array}{c}\text { I agree } \\
\%\end{array}$} & \multicolumn{3}{|c|}{$\begin{array}{c}\text { I do not agree } \\
\%\end{array}$} & \multicolumn{3}{|c|}{$\begin{array}{c}\text { I cannot answer } \\
\%\end{array}$} \\
\hline & SK & $\mathrm{CZ}$ & PL & SK & $\mathrm{CZ}$ & PL & SK & $\mathrm{CZ}$ & PL & SK & $\mathrm{CZ}$ & PL \\
\hline A & 18.12 & 17.11 & 32.61 & 33.66 & 26.32 & 26.09 & 40.78 & 50.00 & 32.61 & 7.440 & 6.580 & 8.700 \\
\hline $\mathrm{I}$ & 8.580 & 6.670 & 13.16 & 20.52 & 24.17 & 18.42 & 61.19 & 60.83 & 56.14 & 9.700 & 8.330 & 12.28 \\
\hline G & 1.820 & 0.000 & 9.760 & 19.09 & 18.52 & 18.29 & 62.73 & 74.07 & 64.63 & 16.36 & 7.410 & 7.320 \\
\hline $\mathrm{N}$ & 0.000 & 0.000 & 16.67 & 0.000 & 0.000 & 50.00 & 66.67 & 50.00 & 0.000 & 33.33 & 50.00 & 33.33 \\
\hline $\begin{array}{l}\text { To- } \\
\text { tal }\end{array}$ & 11.69 & 8.270 & 15.73 & 25.97 & 23.23 & 20.56 & 52.38 & 60.24 & 53.23 & 9.960 & 8.270 & 10.48 \\
\hline
\end{tabular}

Items I get the best advice on the choice of reading material from and I most often discuss what I have read with ... present finding results about specific partners who have an important position (Tab. 5). Partner options come up from the qualitative probe. The most frequent adviser in all national groups is mother. However, fathers appear the least in the Slovak group, while both Czech and Polish respondents report fathers as advisors more often. The choice of father shows statistical significance at the level of $\mathrm{p}<0.001$, this between Slovak and Polish pupils, as well as between Slovak and Czech pupils (Tab. 5). The choice of father shows a statistically significant difference at the level of $\mathrm{p}<0.001$ between Slovak and Polish pupils, as well as between Slovak and Czech pupils also in the item about a partner for discussions about reading. The Polish sample differs also in that up to $40 \%$ of avid readers (A) discuss their reading with someone "from the web" (Babiaková, Kasáčová, Cabanová, 2020, pp. 83 - 84).

The difference in the position of father appears clearly in the analysis by the respondents' reading level. Czech fathers advise both avid readers (A) and interested readers (I) the most, Polish fathers advise more also poor readers (G). Grand parents appear in this position the least in Polish pupils' answers.

There is an obvious difference also in how teachers intervene. Differences in sums in national groups do not differ remarkably. There is a noticeable difference in non-readers ( $\mathrm{G}$ and $\mathrm{N}$ ), where Czech and Polish children report the teacher as an advisor more often (Tab 5). 
Table 5

\begin{tabular}{|c|c|c|c|c|c|c|c|c|}
\hline \multicolumn{9}{|c|}{ I get the best advice on the choice of reading material from } \\
\hline 这 & $\begin{array}{c}\text { Mother } \\
\%\end{array}$ & $\begin{array}{c}\text { Father } \\
\%\end{array}$ & $\begin{array}{c}\text { Teacher } \\
\%\end{array}$ & $\begin{array}{l}\text { Someone } \\
\text { from the } \\
\text { web } \%\end{array}$ & $\begin{array}{c}\text { Sister/ } \\
\text { Brother } \\
\%\end{array}$ & $\begin{array}{c}\text { Friend } \\
\quad \%\end{array}$ & $\begin{array}{c}\text { Grand } \\
\text { parents } \%\end{array}$ & $\begin{array}{c}\mathrm{N} / \% \text { in } \\
\text { national } \\
\text { groups }\end{array}$ \\
\hline A & 51.11 & 9.44 & 4.72 & 1.11 & 11.11 & 16.67 & 5.83 & $309 / 100$ \\
\hline I & 56.11 & 8.58 & 5.94 & 2.64 & 7.26 & 14.85 & 4.62 & $268 / 100$ \\
\hline G & 55.46 & 9.24 & 6.72 & 3.36 & 8.40 & 11.76 & 5.04 & $110 / 100$ \\
\hline $\mathrm{N}$ & 62.50 & 12.50 & 12.50 & 0.00 & 12.50 & 0.00 & 0.00 & $6 / 100$ \\
\hline $\begin{array}{l}\text { SK } \\
\text { Total }\end{array}$ & 53.80 & 9.11 & 5.57 & 2.03 & 9.24 & 15.06 & 5.19 & $693 / 100$ \\
\hline $\mathrm{A}$ & 50.00 & 18.27 & 2.88 & 1.92 & 9.62 & 11.54 & 5.77 & $76 / 100$ \\
\hline $\mathrm{I}$ & 45.29 & 17.06 & 7.65 & 0.59 & 10.59 & 14.12 & 4.71 & $120 / 100$ \\
\hline $\mathrm{G}$ & 47.69 & 4.62 & 9.23 & 4.62 & 7.69 & 24.62 & 1.54 & $54 / 100$ \\
\hline $\mathrm{N}$ & 40.00 & 20.00 & 20.00 & 20.00 & 0.00 & 0.00 & 0.00 & $4 / 100$ \\
\hline $\begin{array}{l}\text { CZ } \\
\text { Total }\end{array}$ & 47.09 & 15.12 & 6.69 & 2.03 & 9.59 & 15.12 & 4.36 & 254100 \\
\hline $\mathrm{A}$ & 38.57 & 15.71 & 2.86 & 1.43 & 12.86 & 18.57 & 10.00 & $46 / 100$ \\
\hline $\mathrm{I}$ & 47.18 & 16.90 & 7.75 & 2.11 & 9.15 & 14.08 & 2.82 & $114 / 100$ \\
\hline $\mathrm{G}$ & 47.25 & 16.48 & 7.69 & 3.30 & 8.79 & 13.19 & 3.30 & $82 / 100$ \\
\hline $\mathrm{N}$ & 33.33 & 11.11 & 22.22 & 0.00 & 22.22 & 11.11 & 0.00 & $6 / 100$ \\
\hline $\begin{array}{l}\mathrm{PL} \\
\text { Total }\end{array}$ & 44.87 & 16.35 & 7.05 & 2.24 & 10.26 & 14.74 & 4.49 & $248 / 100$ \\
\hline
\end{tabular}

A descriptive analysis of the item we talk with teachers about what we are reading in our spare time shows obvious differences in the Polish sample. Polish pupils differ statistically significantly, this at the level of

$\mathrm{p}<0.001$, also in strong agreement in this item, however in favour of Slovak and Czech pupils. Czech and Slovak children give similar answers, but answers of Polish children differ considerably. $41 \%$ of Polish pupils do not talk with teachers about leisure reading and 27\% fail to answer. Discussions with teachers about the read material considerably decline with the level of reading in both levels of agreement. It is the most noticeable in Czech pupils of the subgroup G (Tab. 6). 
Table 6

\begin{tabular}{|c|c|c|c|c|c|c|c|c|c|c|c|c|}
\hline \multicolumn{13}{|c|}{ We talk with teachers about what we are reading in our spare time } \\
\hline \multirow{2}{*}{$\frac{\infty}{d}$} & \multicolumn{3}{|c|}{$\begin{array}{c}\text { I agree very much } \\
\%\end{array}$} & \multicolumn{3}{|c|}{$\begin{array}{c}\text { I agree } \\
\%\end{array}$} & \multicolumn{3}{|c|}{$\begin{array}{c}\text { I do not agree } \\
\%\end{array}$} & \multicolumn{3}{|c|}{$\begin{array}{c}\text { I cannot answer } \\
\%\end{array}$} \\
\hline & SK & $\mathrm{CZ}$ & PL & SK & $\mathrm{CZ}$ & PL & SK & $\mathrm{CZ}$ & PL & SK & $\mathrm{CZ}$ & PL \\
\hline$\overline{\mathrm{A}}$ & 72.82 & 85.53 & 52.17 & 23.30 & 11.84 & 30.43 & 0.65 & 1.32 & 8.70 & 3.24 & 1.32 & 8.70 \\
\hline I & 53.73 & 60.83 & 37.72 & 36.94 & 25.83 & 42.98 & 2.61 & 5.00 & 7.02 & 6.72 & 8.33 & 12.28 \\
\hline $\mathrm{G}$ & 44.55 & 37.04 & 28.05 & 40.91 & 51.85 & 40.24 & 5.45 & 3.70 & 4.88 & 9.09 & 7.41 & 26.83 \\
\hline $\mathrm{N}$ & 50.00 & 25.00 & 33.33 & 33.33 & 25.00 & 16.67 & 0.00 & 0.00 & 0.00 & 16.67 & 50.00 & 50.00 \\
\hline $\begin{array}{l}\text { To- } \\
\text { tal }\end{array}$ & 60.75 & 62.60 & 37.10 & 31.46 & 27.17 & 39.11 & 2.16 & 3.54 & 6.45 & 5.63 & 6.69 & 17.34 \\
\hline
\end{tabular}

The item I only read what I need for school shows a statistically significant difference at the level of $\mathrm{p}<0.001$ between the Slovak and Polish pupils and at the level of $\mathrm{p}<0.01$ between the Slovak and the Czech groups. Slovak children disagree with the statement that they only read what need for school the most. There is a difference between avid readers (A) and interested readers (I) against readers without interest $(G)$. Our criterion of the original division into these reading levels is confirmed. The level $G$ differs precisely in that they read only what they must. They do not form a relationship to literature and reading for relaxation and experience. Disagreement is expressed by as many as $73.5 \%$ of Slovak pupils who are mainly from the subgroup A and I, thus those who are active readers (Tab. 7).

Table 7

\begin{tabular}{|c|c|c|c|c|c|c|c|c|c|c|c|c|}
\hline \multicolumn{13}{|c|}{ I only read what I need for school } \\
\hline \multirow{2}{*}{$\frac{\infty}{d}$} & \multicolumn{3}{|c|}{$\begin{array}{c}\text { I agree very much } \\
\% \\
\end{array}$} & \multicolumn{3}{|c|}{$\begin{array}{c}\text { I agree } \\
\% \\
\end{array}$} & \multicolumn{3}{|c|}{$\begin{array}{c}\text { I do not agree } \\
\%\end{array}$} & \multicolumn{3}{|c|}{$\begin{array}{c}\text { I cannot answer } \\
\%\end{array}$} \\
\hline & SK & $\mathrm{CZ}$ & PL & SK & $\mathrm{CZ}$ & PL & SK & $\mathrm{CZ}$ & PL & SK & $\mathrm{CZ}$ & PL \\
\hline A & 2.27 & 7.89 & 0.00 & 3.56 & 1.32 & 4.35 & 92.56 & 86.84 & 93.48 & 1.62 & 3.95 & 2.17 \\
\hline I & 7.84 & 9.17 & 8.77 & 14.93 & 13.33 & 14.04 & 70.52 & 74.17 & 71.05 & 6.72 & 3.33 & 6.14 \\
\hline G & 18.18 & 22.22 & 34.15 & 30.91 & 37.04 & 19.51 & 30.00 & 22.22 & 31.71 & 20.91 & 18.52 & 14.63 \\
\hline $\mathrm{N}$ & 0.00 & 0.00 & 16.67 & 66.67 & 0.00 & 66.67 & 16.67 & 25.00 & 16.67 & 16.67 & 75.00 & 0.00 \\
\hline $\begin{array}{l}\text { To- } \\
\text { tal }\end{array}$ & 6.93 & 11.42 & 15.73 & 12.84 & 14.57 & 15.32 & 73.45 & 66.14 & 60.89 & 6.78 & 7.87 & 8.06 \\
\hline
\end{tabular}




\section{Discussion}

Our research findings allow us to summarize the following suggestions for discussion:

- Children aged 9-10 years enjoy reading with somebody; they either listen to somebody or read to them themselves. It is associated with social sharing of mediated experiences. The literary content thus becomes something that brings people closer together, what they have in common, what they look forward to. Poland as the first of the compared countries took the national initiative Cala Polska czyta dzieciom, currently inspiring both the Czech Republic and Slovakia (Kováčová-Švecová \& Simanová, 2020).

- There is a significant difference between Slovak and Czech pupils in their liking for reading to somebody else. Children at this age, when learning to read, enjoy reading with somebody, they either listen or read to somebody themselves. However, the liking for reading to somebody else declines with the declining level of reading in the subgroups A, I, G, N in all national groups. Our other analysis comparing Slovak pupils of the $4^{\text {th }}$ and $7^{\text {th }}$ classes shows that the liking for reading together declines with age (Babiaková, Kasáčová, Cabanová, 2020, pp. 45 - 56).

- Polish pupils more than Czech pupils read aloud in front of the entire class. It is system part of education at the primary level. This activity is not pleasant for all. Some may find it even stressful. There may be various reasons: poor reading skill, speech disorders, tension in social relations, bad classroom climate, teacher's approach, etc. Overall, it can be stated that in particular Czech children dislike reading aloud in public. It is well known that the Polish curriculum highly accentuates this skill.

- Father appears as an advisor and partner for talks about reading the least in Slovak children. Mothers are interested in children's reading the most in all groups.

- Teacher as an advisor and partner is reported only by a low percentage of pupils in all national groups.

- Polish pupils significantly differ from Slovak and Czech pupils in talking with teachers about what they are reading in their free time. Reading programmes in Poland are tied to specific, recommended titles that are worked with in classes. There is a sufficient reading potential in Slovak pupils, but teachers do not discuss about voluntary choices of literature. 


\section{Conclusions and recommendations}

We see limitations of our research in some phenomena. The individual national samples are not of the same size; distribution of the reading level inside the samples also varies. The tool used is of a nominal nature, which limits the choice of statistical procedures for statistical processing.

The strength of the research is its authenticity, since the research tool is designed because of initial exploration of the issue by a qualitative strategy based on interviews with focus groups of children. This is also a limitation in international comparison because the interviews were made only in Slovak schools. The significance of the international comparison rests also in the evidence of the influence of current conceptions of education and training in the above countries on the social context of younger pupils' reading.

Teachers certainly do develop reading literacy, but contribute minimally to the development of reading as a hobby. We consider this one of the most important research findings. We interpret it in a broader context. We think that teachers should give space and time to talks about leisure reading and extracurricular choice of books. It is important for the knowledge about pupils' reading interest and the pedagogical, literary and aesthetic influence on it. It is necessary also for understanding the pupils' conceptions of reading and reading skills (Renuga, Kanchana, 2015).

\section{References}

Australian Kids and Family Reading Report. (2016). Engaging teens with reading. online [2019-08-12]. Retrieved from <https://natlib.govt.nz/schools/reading-engagement/ strategies-to-engage-students-as-readers/engaging-teens-with-reading>

Babiaková, S. \& Kasáčová, B. (2020). Reading Preferences of Younger Learners in Slovak-Czech-Polish comparison, The New Educational Review 61( 3), 38-50

Babiaková, S. \& Kasáčová, B. (2020). Social Context of Child Reading in Ontogenetic ComparisonIn EDULEARN 20 Proceedings, $12^{\text {th }}$ International Conference on Education and New Learning Technologies, (pp. 6341-6351)

Babiaková, S., Kasáčová, B. \& Cabanová, M. (2020). Čítanie a čitatelstvo slovenských detí. Výskum detského čitatelstva a medzinárodné komparácie. (Reading and Reading Habits of Slovak Children. Research of Children's Reading and International Comparisons). Banská Bystrica/Slovakia: Belianum.

Chaves, Ch. (2017) Book Reading among Filipino Children Wanes. In Mannila Bulletin. The Nation's Leading Newspaper, 2017. [online]. [2019-11-25]. Retrieved from: <https:// news.mb.com.ph/2017/07/23/book-reading-among-filipino-children-wanes/> 
Ducharme, J. (2019) A Third of Teenagers Don't Read Books for Pleasure Anymore. 2018. online [2019-07-10]. Retrieved from <https://time.com/5371053/teenagers-books-social-media/>

Durik, A, M., Vida, M. \& Eccles, J.S. (2006). Ask values and ability beliefs as predictors of high school literacy choices: A developmental analysis. In Journal of Educational Psychology, 98 (2), 382-393

Kováčová-Švecová, Z. \& Simanová, L. (2020). Čítanie a čitatelstvo slovenských detí. Metodika na podporu čitatel'stva žiakov v mladšom školskom veku. (Reading and Reading Habits of Slovak Children. Teaching Methodology for Support of Younger Pupils'Reading). Banská Bystrica/Slovakia: Belianum. Vydavatel'stvo Univerzity Mateja Bela v Banskej Bystrici

Levy, R. (2011). Young children reading. University of Sheffield, UK: Sage Publishing.

Loh, Ch. E. \& Baoqi, S. I'd Still Prefer to Read the Hard Copy": Adolescents' Print and Digital Reading Habits. In Journal of Adolescent \& Adult Literacy, 2018. [online]. [2019-11-25]. Retrieved from < https://www.researchgate.net/publication/327114576_I'd_Still_Prefer_to_Read_the_Hard_Copy_Adolescents'_Print_and_Digital_Reading_Habits $>$.

PIRLS (2016). International Results in Reading. Retrieved 12/03/2020: http://pirls2016. org/pirls/student-achievement/pirls-achievement-results/

Renuga, M., \& Kanchana Mala, B. (2015). Students' Perceptions of Themselves as Readers and the Concept of Reading. The New Educational Review, 41( 3), 86-97

Rideout, V.J. (2014) Children, Teens and Reading: A Common Sense Media Research Brief, Common Sense Media, 2014. [online] [2018-04-25]. Retrieved from <http://www.iserotope.com/wp-content/uploads/2014/05/csm-children-teens-and-reading-2014.pdf > 